\title{
Characteristics Shaping College Student Organizational Citizenship Behavior
}

\author{
Cary J. LeBlanc, Assumption College, USA
}

\begin{abstract}
This study explored the concept of Organizational Citizenship Behavior (OCB) in relation to undergraduate college students. The extensive research on $O C B$ within traditional work environments indicates that while workers who demonstrate $O C B$ usually receive more favorable performance evaluations, those behaviors also help build community and culture within the organization. This study expands the extant research by examining $O C B$ of college students, where very few studies exist. For this research 490 undergraduate students completed an online survey, where we looked to identify correlations between OCB and four variables: gender, year in school, religious practice, and major. The statistically significant correlation between three of these variables and $O C B$ will help faculty and student life staff identify and encourage OCB in their students. It will also help students be more successful in school, help prepare them for careers, while also enriching the college community.
\end{abstract}

Keywords: Organizational Citizenship Behavior and College Students Majors; Gender, Religiosity; Level

\section{INTRODUCTION}

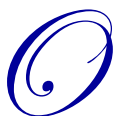

rganizational Citizenship Behavior (OCB) as a concept was first identified by Smith, Organ, and Near (1983) as "one manifestation of a broader disposition toward prosocial behavior" (p. 656). Their study sought to define citizenship behavior as well as identify the predictors of such behavior. The most widely accepted description comes from Organ, who perceives OCB as "individual behavior that is discretionary, not directly or explicitly recognized by the formal reward system, and in the aggregate promotes the efficient and effective functioning of the organization" (1988). While this construct has been supported and challenged (Podsakoff \& MacKenzie, 1997; Hoffman, Blair, Meriac, \& Woehr, 2007; LePine, Erez, \& Johnson, 2002; Borman, 2004), including by Organ himself (1997), the consensus is that this definition provides researchers with a strong definition from which to expand our understanding of OCB.

The focus of inquiry for much of the existing research has been on individuals, while an increasing number of studies examine the effects of OCB on the whole organization (Borman, Penner, Allen, \& Motowidlo, 2001; Podsakoff \& MacKenzie, 1997; Organ, 1997). These studies conclude that while individual in nature, OCB helps to build a sense of community, culture, and enhanced organizational performance. Borman (2004) claims that OCB in the context of organizational, social, and psychological context "serves as the critical catalyst for tasks to be accomplished" (p. 238). Individuals performing voluntary actions that are extra-role, beyond those explicitly required in a job description, are the type of behavior also recognized by supervisors. These efforts (OCB) are increasingly being rewarded in positive evaluations, which lead to increased salaries, status, opportunities, promotions, and retention.

As stated earlier, most research on OCB has focused on workers and issues related to traditional work settings. Researchers have examined numerous variables (antecedents) in an effort to improve our understanding of what OCB is and what prompts it. Studies cover a wide range of OCB individual characteristics, including transformational leaders (Podsakoff, MacKenzie, Moorman, \& Fetter, 1990; Nguni, Sleegers, \& Denessen, 2006), personality (Borman, 2004), gender (Farrell \& Finkelstein, 2005), task performance (Motowidlo \& Van Scotter, 1994; Bachrach, Powell, Bendoly, \& Richey, 2006), age (Wanzian, 2006), and time pressure (Hui \& Organ, 1994). In all of these studies the focus has been on various antecedents that accompany individual manifestations of OCB. While the consequences of OCB have been studied, there is not yet a substantial body of work to draw significant 
conclusions. However, the studies examining antecedents show much stronger evidence for positive correlations demonstrating how OCB helps the organization.

In their 2009 meta-analysis, Podsakoff, Whiting, Podsakoff, and Blume identified over 200 articles published on OCB. The majority of these studies examined OCB within the context of traditional work organizations. Allison, Voss, and Dryer (2001) pointed out the concept is "largely been ignored in business education" (p. 282), though college as an organization has had limited studies. Specifically, college environments as a type of work organization have been examined; however, these studies have looked to identify and encourage OCB of faculty (Kagaari \& Munene, 2007; Ertuk, 2007; Skarlicki \& Latham, 1995). While faculties are one of the most important groups on campus, students, administration, and staff also play key roles. Khalid (2010), in his study of lecturer OCB and student achievement, noted the lack of research of OCB toward college students stating, "there is a dearth of empirical research exploring this concept in the context of the university" (p. 69).

Why is this of concern? It can be argued that one of the primary functions of college is to prepare students for future careers. In particular, students in business-related majors are preparing to be future managers and leaders, and understanding OCB, in addition to helping the individual, will also likely assist managers in motivating and rewarding employees. In essence, understanding OCB will help students' careers and the organizations where they work, along with helping students improve academically and other areas considered integral to a college education. Kernodle and Noble, in their conceptual article (2013), clearly see that applying more emphasis on OCB will serve these purposes.

The benefits to making students aware of and developing OCB in them are not limited to vocational advantages. The college itself as an organization is more than just the classroom and it benefits when students, faculty, and staff exhibit OCB. The actions of all members of the college community help the organization operate effectively. Much like a typical work organization, where the employees go beyond their roles and take part in behaviors that enhance the work environment, students do so by "helping fellow students academically and socially, contributing to local community service efforts, and helping to recruit new students are all OCBs that most academic institutions depend on and encourage" (Schmitt, Keeney, Oswald, Kim, Imus, Merritt, Friede, \& Shivpuri 2007, p. 167).

It is important here to place into context the role of a college student, as viewed on a continuum. At one end of the continuum is a very narrowly defined role, which consists of attending class, writing papers, and taking exams in order to earn credits. Few, if any, additional behaviors are required to earn a degree, except having to pay tuition. At the other end are those students who in addition to earning credits, may do any one or more of the following: live on campus, take honors courses, join clubs, run for student government, play sports, work on campus, help their fellow classmates in the classroom and the dorm, and a myriad of other ways students are engaged on a college campus and surrounding community. In the narrow role those limited activities are considered in-role behaviors in that like OCB for workers, earning credits is "rewarded" by the organization. Gain enough credits along with a minimum GPA and students earn a degree. As we move down the continuum activities increasingly become OCB, or extra-role behavior. These are "extra-role" as they are not necessarily needed to graduate with a degree, nor rewarded in credits. However, by performing OCB a student is more likely to be involved and engaged in a more complete college experience. According to Astin (1977), "The quality or intensity of the student's college experience can be measured in terms of student involvement in the college environment" (p. 21). By being involved in various ways while in college, students are helping themselves to more fully develop. After all, while there are many reasons why one attends college, it is safe to say that traditional undergraduate students (18-22 years of age) are more likely to look to develop themselves beyond academics. Astin's view is that the overall purpose of college is to "enhance the students functioning" (p. 11). The college plays a role by providing the types of courses, programming, residence halls, and campus environment students need to learn and develop. Students "functioning" is enhanced when they take advantage of what is offered, helping them develop and succeed in college and as a citizen in future careers as well.

Additionally, Pascarella and Terenzini (1991) found evidence in their research that the long-term effects of college are not just in "occupations and earnings" (p. 573). Their synthesis claims that attending college "influences cognitive, social, and psychological characteristics." These are areas where OCB can be of substantial aid to students in college, while also helping them in the future to be better employees and managers. 
Riker and Decoster (2008) argue that it is "simply not possible to disembody the human personality and develop a student's intellectual capacities in isolation from his cultural, spiritual, and psychological growth" (p. 92). This contention speaks to what most students experience in a traditional undergraduate degree program. By understanding factors that lead students to exhibit OCB, colleges may be better prepared to identify and encourage these behaviors that will benefit students, the college community, and future employers.

\section{RESEARCH STUDY}

In this study we looked to identify several demographic characteristics and determine if these act as antecedents for what we are calling College Student OCB (CS-OCB). We were interested in learning whether college students are pre-disposed to OCB based on selected demographic variables. We surmised that other life experiences and conditions serve to help students exhibit OCB. Citizenship behaviors are driven not only by the act of arriving on a college campus and becoming an undergraduate student. Specifically, there are existing conditions and/or life selections that help make some students more likely to perform extra role behaviors.

We developed four hypotheses examining the relationship between OCB and variables relevant to college students:

Hypothesis 1: Gender is positively related to actual engagement/professed willingness to exhibit OCBs.

Hypothesis 2: Religious affiliation is positively related to actual engagement/professed willingness to exhibit OCBs.

Hypothesis 3: Undergraduate year-in-school is positively related to actual engagement/professed willingness to exhibit OCBs.

Hypothesis 4: Undergraduate major is positively related to actual engagement/professed willingness to exhibit OCBs.

\section{Procedure}

Research participants were recruited from a small liberal arts college in the Northeastern United States. This was a convenience to the researchers who were members of this community. To enhance our online survey response rate, we utilized the well established Dillman, Smyth, and Christian (2009) survey research methodology. This online survey methodology consisted of a series of timely emails, which included a pre-notice letter, initial invitation, followed by two subsequent email reminders (sent only to those research participants who had not yet participated), and a final thank you email upon completion. As an incentive to promote participation, research participants who completed the survey were placed into a drawing for one of four $\$ 25$ American Express gift cards. Gift card winners were randomly selected.

The targeted population was 2004 undergraduate students, of which 490 completed the survey, achieving an overall response rate of $24.5 \%$.

\begin{tabular}{|l|}
\hline \multicolumn{1}{|c|}{ Demographics } \\
Gender \\
Female $=356(72.7 \%)$ \\
Male $=134(27.3 \%)$ \\
Year in School \\
\hline Freshman $=87(17.7 \%)$ \\
Sophomore $=125(25.5 \%)$ \\
Junior $=147(30 \%)$ \\
Senior $=131(26.7 \%)$ \\
Religious Affiliation \\
Devout $=66(13.6 \%)$ \\
Practicing $=216(44 \%)$ \\
Non-Practicing $=158(32.2 \%)$ \\
Not Affiliated $=50(10.2 \%)$ \\
\hline
\end{tabular}




\section{College Major Categories}

While Hypothesis 4 looked to find a correlation between individual college majors and OCB we realized that the number of responses for a single major would not provide enough data. We then combined majors into four categories, which were coded for analysis. The categories and the number of respondents in each are as follows:

- $\quad$ AMTUMSS $=234(47.8 \%)$ - This category includes students who have identified their academic major in the fields of art, music, theatre, education, humanities, and social sciences.

- $\quad$ BUSMATH $=193(39.4 \%)$ - This category includes students who have identified their academic majors in the fields of business, computer science, economics, and mathematics.

- $\quad \mathrm{NATSCI}=51(10.4 \%)$ - This category includes students who have identified their academic majors in the fields of biology, chemistry, environmental science, geography, molecular biology, and natural sciences.

- $\quad \mathrm{UNDEC}=12(2.4 \%)$ - This category includes students who not yet identified with an academic major. At this institution students are required to officially declare a major in the spring semester of their sophomore year, though they may declare before that.

\section{Measures}

We measured OCB using the 24-item scale developed by Podsakoff, MacKenzie, Moorman, and Fetter (1990). This scale was chosen for its sound psychometric properties and extensive use in previously published OCB research. The Podsakoff et al. (1990) scale also successfully captured the following five major factors of OCB, including altruism, conscientiousness, sportsmanship, courtesy, and civic virtue.

In addition, we included two items from the scale developed by Allison, Voss, and Dryer (2001); these targeted the daily activities of the sample college student population. These additional items related to both "cheerleading," and "peacemaking." The former action refers to encouraging other students and the latter acting as a stabilizing influence in classes or teams, as well as working to keep the peace when other students have disagreements.

The wording of certain questions from the Podsakoff, MacKenzie, Moorman, and Fetter (1990) scale was changed slightly in order to conform to that of the 2001 Allison, Voss, and Dryer study. In the scale used for this study, participants were asked to indicate their agreement or disagreement items using a 7-point Likert scale ranging from "strongly disagree" through "strongly agree." Slight modification to the original scale items was needed to fit our target research participants (i.e., undergraduate students), since the original scale was intended for research participants currently employed in a traditional business setting.

\section{RESULTS}

The first hypothesis regarding Gender is positively related to actual engagement/professed willingness to perform OCBs. Analysis of general statistics and t-test resulted in an OCB Total means (out of potential high score of 190) for males 142.2239 and females 145.8202 and significance for females at .016. Data Tables A and B are provided here:

Data Table A - OCB Total Male and Female - Group Statistics

\begin{tabular}{|cccccc|}
\hline & Sex & N & Mean & Std. Deviation & Std. Error Mean \\
\hline \multirow{2}{*}{ OCB Total } & Male & 134 & 142.2239 & 15.5755 & 1.34552 \\
& Female & 356 & 145.8202 & 14.25408 & 0.75546 \\
\hline
\end{tabular}

Data Table B - OCB Total Male and Female - t-test

\begin{tabular}{|llccccc|}
\hline & & F & Sig. & t & df & Sig. (2-tailed) \\
\hline \multirow{2}{*}{ OCB Total } & Equal variances assumed & 1.052 & 0.306 & -2.426 & 488 & 0.016 \\
& Equal variances not assumed & & & -2.331 & 221.814 & 0.021 \\
\hline
\end{tabular}


As a result of these statistics we were able to reject the null hypothesis. Consistent with past research, females presented with higher levels of OCB than males. We believe that although just a snapshot in time, the data aligns with what is happening on college campuses today. More women than men (approximately a 60/40 split) are attending college as traditional undergraduate students and as such behavioral shifts, in particular OCB of women could very well be influencing the dynamics in the classroom, along with the broader college community. This is an area future research could help identify.

Hypothesis 2, which stated religious affiliation is positively related to actual engagement/professed willingness to perform OCBs, was supported by the data and we were able to reject the null hypothesis. Data supporting this comes in the way of comparing the devout category with the three other categories of religious affiliation. Respondents stating they are devout had a mean OCB of 152.8030, as compared to the means of the other three levels of religious practice: not currently affiliated $=141.2400$, non-practicing $=142.7278$, and practicing $=$ 144.7778. These are depicted below in Data Table C. We ran a one-way ANOVA revealing significance score of .000 for devout as shown in Data Table D.

Data Table C - OCB Total Religious Affiliation - One-Way

\begin{tabular}{|lcccc|}
\hline \multicolumn{1}{|c}{ OCB Total } & N & Mean & Std. Deviation & Std. Error Mean \\
\hline Not Currently & 50 & 141.24 & 15.34576 & 2.17022 \\
Non-Practicing & 158 & 142.7278 & 13.72647 & 1.09202 \\
Practicing & 216 & 144.7778 & 14.52877 & 0.98856 \\
Devout & 66 & 152.803 & 14.47036 & 1.78118 \\
Total & 490 & 144.8367 & 14.69895 & 0.66406 \\
\hline
\end{tabular}

Data Table D - OCB Total Religious Affiliation - Post Hoc Multiple Comparisons

\begin{tabular}{|c|c|c|c|c|c|c|}
\hline \multirow{2}{*}{$\begin{array}{l}\text { (I) Which one of } \\
\text { the following } \\
\text { statements would } \\
\text { you most likely } \\
\text { endorse? }\end{array}$} & \multirow{2}{*}{$\begin{array}{l}\text { (J) Which one of } \\
\text { the following } \\
\text { statements would } \\
\text { you most likely } \\
\text { endorse? }\end{array}$} & \multirow[b]{2}{*}{$\begin{array}{c}\text { Mean Difference } \\
(\mathbf{I}-\mathbf{J})\end{array}$} & \multirow[b]{2}{*}{ Std. Error } & \multirow[b]{2}{*}{ Sig. } & \multicolumn{2}{|c|}{ 95\% Confidence Interval } \\
\hline & & & & & $\begin{array}{l}\text { Lower } \\
\text { Bound }\end{array}$ & $\begin{array}{l}\text { Upper } \\
\text { Bound }\end{array}$ \\
\hline \multirow[t]{3}{*}{ not currently } & non-practicing & -1.48785 & 2.32888 & 0.523 & $\begin{array}{l}-6.0638 \\
\end{array}$ & 3.0881 \\
\hline & practicing & -3.53778 & 2.25247 & 0.117 & -7.9636 & 0.888 \\
\hline & devout & -11.56303 & 2.69093 & 0 & -16.8503 & -6.2757 \\
\hline \multirow[t]{3}{*}{$\underline{\text { non-practicing }}$} & not currently & 1.48785 & 2.32888 & 0.523 & -3.0881 & 6.0638 \\
\hline & practicing & -2.04993 & 1.50248 & 0.173 & -5.0021 & 0.9022 \\
\hline & devout & -10.07518 & 2.10355 & 0 & -14.2084 & -5.942 \\
\hline \multirow[t]{3}{*}{ practicing } & not currently & 3.53778 & 2.25247 & 0.117 & -0.888 & 7.9636 \\
\hline & non-practicing & 2.04993 & 1.50248 & 0.173 & -0.9022 & 5.0021 \\
\hline & devout & -8.02525 & 2.01862 & 0 & -11.9916 & -4.0589 \\
\hline \multirow[t]{3}{*}{$\underline{\text { devout }}$} & not currently & 11.56303 & 2.69093 & 0 & 3.2757 & 16.8503 \\
\hline & non-practicing & 10.07518 & 2.10355 & 0 & 5.942 & 14.2084 \\
\hline & practicing & 8.02525 & 2.01862 & 0 & 4.0589 & 11.9916 \\
\hline
\end{tabular}

The data above clearly identifies students who consider themselves devout members of religious faiths present with higher levels of OCB. Those who reported practicing their faith regularly are much more inclined to OCB. While in general people who have a stronger faith (religiousness) may be more inclined to have OCB, it is interesting to see college students with stronger faith practices expressing OCB to such a strong degree in a college environment. This is especially true when we consider several other areas of development of traditional undergraduate college students that are also vying for their attention. As we look ahead, it is perhaps beneficial to consider how colleges with religious affiliations, as well as secular institutions might want to provide more resources for religious identity and/or spiritual growth.

Hypothesis 3, relating to undergraduate year in school, did not show statistical significance which was a bit of a surprise. Especially, since our prediction was based on the assumption that the longer one stays with an organization, the more likely they are to grow in their commitment. In fact, as can be seen in Data Table E (below) 
the means for Freshman and Seniors are 146.86 and 142.93 respectively, which is the opposite from what we expected.

Data Table E - OCB Total Year in School - One-Way

\begin{tabular}{|lcccc|}
\hline \multicolumn{1}{|c}{ OCB Total } & N & Mean & Std. Deviation & Std. Error Mean \\
\hline Freshman & 87 & 146.8621 & 13.37402 & 1.43385 \\
Sophomore & 125 & 146.312 & 15.06995 & 1.3479 \\
Junior & 147 & 144.0884 & 14.35076 & 1.18363 \\
Senior & 131 & 142.9237 & 15.4051 & 1.34595 \\
Total & 490 & 144.8367 & 14.6985 & 0.66403 \\
\hline
\end{tabular}

Data Table F - OCB Total Year in School - Post Hoc Multiple Comparisons

\begin{tabular}{|c|c|c|c|c|c|c|}
\hline \multirow{2}{*}{$\begin{array}{l}\text { (I) What level } \\
\text { of college did } \\
\text { you most } \\
\text { recently } \\
\text { complete? }\end{array}$} & \multirow{2}{*}{$\begin{array}{l}\text { (J) What level } \\
\text { of college did } \\
\text { you most } \\
\text { recently } \\
\text { complete? }\end{array}$} & \multirow[b]{2}{*}{ Mean Difference (I -J) } & \multirow[b]{2}{*}{ Std. Error } & \multirow[b]{2}{*}{ Sig. } & \multicolumn{2}{|c|}{ 95\% Confidence Level } \\
\hline & & & & & $\begin{array}{l}\text { Lower } \\
\text { Bound }\end{array}$ & $\begin{array}{l}\text { Upper } \\
\text { Bound }\end{array}$ \\
\hline \multirow{3}{*}{ Freshman } & Sophomore & 0.55007 & 2.04699 & 0.788 & -3.472 & 4.5721 \\
\hline & Junior & 2.77363 & 1.98313 & 0.163 & -1.1229 & 6.6702 \\
\hline & Senior & 3.9384 & 2.02766 & 0.053 & -0.0457 & 7.9225 \\
\hline \multirow[t]{3}{*}{ Sophomore } & Freshman & -0.55007 & 2.04699 & 0.788 & -4.5721 & 3.472 \\
\hline & Junior & 2.2256 & 1.78374 & 0.213 & -1.2812 & 5.7284 \\
\hline & Senior & 3.38834 & 1.83312 & 0.065 & -0.2135 & 6.9902 \\
\hline \multirow[t]{3}{*}{ Junior } & Freshman & -2.77363 & 1.98313 & 0.163 & -6.6702 & 1.1229 \\
\hline & Junior & -2.22356 & 1.78374 & 0.213 & -5.7284 & 1.2812 \\
\hline & Senior & 1.16477 & 1.76153 & 0.509 & -2.2964 & 4.6259 \\
\hline \multirow[t]{3}{*}{ Senior } & Freshman & -3.9384 & 2.02766 & 0.053 & -7.9225 & 0.0457 \\
\hline & Sophomore & -3.38834 & 1.83312 & 0.065 & -6.9902 & 0.2135 \\
\hline & Junior & -1.16477 & 1.76153 & 0.509 & -4.6259 & 2.2964 \\
\hline
\end{tabular}

Study results for the level of college completed suggests that a college senior is not more inclined to exhibit OCB toward the institution. As a result we accepted the null hypothesis. From this we are able to discern that organizational commitment, as it may be expressed as OCB, is not a consequence of the class-level of traditional undergraduate students. It is clear that the other characteristics measured, especially gender and strength of religious practice, are much more influential in predicting whether a student will exhibit OCB. Then to what can we infer from these findings? We now believe that while senior-level college students may be just as committed to their institution, if not more, they are likely in a phase of development where their focus is on life after college. As such, attention may be much more aligned with achieving personal goals and the start of the job search process, leaving less time for OCB.

Results relating to Hypothesis 4, undergraduate major is positively related to actual engagement/professed willingness in OCB, revealed that in a Post Hoc test running multiple comparisons AMTUMSS (art, music, theatre, education, humanities, and social sciences) showed .001 significance in comparison with BUSMATH (business, computer science, economics, and mathematics) (See Data Table G). 
Data Table G - OCB Major Categories- Post Hoc Multiple Comparisons

\begin{tabular}{|c|c|c|c|c|c|c|}
\hline \multirow{2}{*}{$\begin{array}{l}\text { (I) Major } \\
\text { Categories }\end{array}$} & \multirow{2}{*}{$\begin{array}{l}\text { (J) Major } \\
\text { Categories }\end{array}$} & \multirow{2}{*}{$\begin{array}{c}\text { Mean Difference } \\
(\mathbf{I}-\mathbf{J})\end{array}$} & \multirow{2}{*}{ Std. Error } & \multirow{2}{*}{ Sig. } & \multicolumn{2}{|c|}{ 95\% Confidence Level } \\
\hline & & & & & Lower Bound & Upper Bound \\
\hline \multirow[t]{3}{*}{ AMTHUMSS } & BUSMATH & 4.81174 & 1.41424 & 0.001 & 2.033 & 7.5905 \\
\hline & UNDEC & -0.66667 & 4.30493 & 0.877 & -9.1252 & 7.7919 \\
\hline & NATSCI & -0.47059 & 2.24764 & 0.834 & -4.8869 & 3.9457 \\
\hline \multirow[t]{3}{*}{ BUSMATH } & AMTHUMSS & -4.81174 & 1.41424 & 0.001 & -7.5905 & -2.033 \\
\hline & UNDEC & -5.47841 & 4.32717 & 0.206 & -13.9807 & 3.0239 \\
\hline & NATSCI & -5.28233 & 2.28996 & 0.021 & -9.7818 & -0.7829 \\
\hline \multirow[t]{3}{*}{ UNDEC } & AMTHUMSS & 0.66667 & 4.30493 & 0.877 & -7.7919 & 9.1252 \\
\hline & BUSMATH & 5.47841 & 4.32717 & 0.206 & -3.0239 & 13.9807 \\
\hline & NATSCI & 0.19608 & 4.6665 & 0.967 & -8.9729 & 9.3651 \\
\hline \multirow[t]{3}{*}{ NATSCI } & AMTHUMSS & 0.47059 & 2.24764 & 0.834 & -3.9457 & 4.8869 \\
\hline & BUSMATH & 5.28233 & 2.28996 & 0.021 & 0.7829 & 9.7818 \\
\hline & UNDEC & -0.19608 & 4.6665 & 0.967 & -9.3651 & 8.9729 \\
\hline
\end{tabular}

This finding for college major categories supports our belief that academic major, or more specifically the characteristics of the students selecting a particular major category, would exhibit higher OCB. It is therefore not surprising that the AMTUMSS category, which includes students majoring in human services and psychology ("social sciences" in our categorization), which are considered helping professions and therefore already inclined to exhibit OCB. These two are also in the top ten of majors at this college and represented $39.74 \%$ of survey respondents (93 out of 234) in this major category and 19\% (93 out of 490) of total respondents.

\section{IMPLICATIONS AND RECOMMENDATION FOR FACULTY AND STUDENT LIFE STAFF}

It is clear from this research that students with certain demographic characteristics are more inclined to exhibit OCB. As faculty and others involved in the development of college students, what can we do to both identify and encourage OCB? We can begin by acknowledging the influence women are having and will continue to have on college campuses as they are currently at or near $60 \%$ of traditional undergraduate students. This means that future work organizations will be infused with women who are college graduates. As such OCB, which is more strongly exhibited by women more than men, will become that much more integrated into work organizations. This has the potential to significantly alter those work organizations that have been traditionally male dominated. Colleges will then need to integrate more fully into their classrooms and dormitories, along with many other parts of college life, a more full understanding of $\mathrm{OCB}$ and its affect on individual performance and organizational success. Women will need to be provided the opportunity to practice OCB in a learning environment that will nurture and strengthen their already very positive OCB characteristics.

We also need to understand more fully how this gender dynamic, on the campus and future work environment, affects men. Acknowledging OCB as practiced by women, who are the majority of undergraduate students and future workforce for college graduates, will very likely mean changes in performance expectations (measurements) and the way organizations are managed.

In accordance with Hypothesis 2, the results showed overall those who are more devout members of a religious faith presented with higher levels of OCB. This suggests that if more students are encouraged and supported to develop their religious practices and faith, the presence of OCB would grow. An institution that is faith-based may already possess the organization and structure to support this effort. However, sectarian colleges and universities where there may be Newman (Catholic), Hillel (Jewish), and Christian centers all provide programs to encourage, continue, and grow faith identity and development of college students. If one of these options are available, then willing faculty and/or staff could help create opportunities and programs for students' to practice and develop their faith.

Lastly, regarding college majors, it would seem one of the key questions is: How do we help students majoring in fields other than the helping professions, art, and music, develop awareness of and behaviors consistent 
with OCB? This is especially important as a key belief framing our study is OCB is important to and valued by work organizations. Students then need to know what OCB are and how do they develop these workplace-preferred behaviors. Strongly encouraging students' participation in the many offerings of the college community could go a long way in providing actual experience with OCB that should then be noted as such by faculty and staff. Perhaps co-curricular activities that include a service component will promote OCB and foster these behaviors beyond the community setting where the service is completed. This type of socialization, in which OCB is practiced, will no doubt advance the mission of those involved in student life that provide valuable learning opportunities and environments outside of the classroom.

\section{LIMITATIONS OF STUDY AND RECOMMENDATIONS FOR FUTURE RESEARCH}

Considering all aspects of our study, we can conclude the data provides meaningful information and a framework for future research. Still, there are a few methodological issues that need to be addressed. The population studied was not obtained via random method. This potentially influences the results; for higher OCB, students are more likely to complete surveys, especially females. A future study may benefit from a randomized sample, or at minimum a mixed mode distribution in an effort to gain more participants. Especially those who may be less predisposed of completing a survey considered to be OCB.

Another limitation to this study was time constraints. This particular research project took place over the summer, which limited contact with potential participants. Since classes were not in session, it made it less necessary for students to access their school email accounts. As this study showed women, more than men, were paying attention to their email and therefore responded in greater numbers than men. Still, our response rate was quite high considering this time-of-year constraint. And obviously with over $70 \%$ of the respondents being female, and their propensity toward $\mathrm{OCB}$, their responses influenced the data. Although the actual population at this institution is $59 \%$ female compared to $41 \%$ were male, the females were almost three times the male respondents, $73 \%$ vs. $27 \%$ respectively.

\section{Possible Future Areas of Study}

- $\quad$ Expand the research to include a range of public and private colleges and universities in order to compare OCB levels among these different institutions.

- $\quad$ Compare colleges with religious affiliation versus secular colleges without religious affiliation.

- $\quad$ Examine the relationship between education level and willingness to engage in OCB.

- $\quad$ Explore age and willingness to engage in OCB in a larger-scale study with a broader range of ages.

Overall, the successes of the present study will open up further research and inquiry into Organizational Citizenship Behavior in academia. Potential future studies focused on undergraduate students may develop a more complete understanding of College Student-OCB. Additionally these studies will help examine how faculty, student life staff, and others in the college community come together to identify and encourage extra-role behaviors that constitute OCB. Finally, identifying OCB as it exists on a college campus may help the college differentiate from competitors since OCB helps to build the community in which a student experiences a more full developmental educational experience.

\section{AUTHOR INFORMATION}

Dr. Cary LeBlanc came to academia after twenty-five years in industry, where he held various management and consulting roles in the field of human resources. He has organizational development experience ranging from small start ups to Fortune 100s. For much of his consulting he specialized in building scientific research and development teams. In his current faculty position he teaches both marketing and management in the undergraduate college as well as the MBA program. His scholarly interests have been focused on organizational citizenship behavior, job satisfaction, and corporate social responsibility and sustainability. E-mail: caleblanc@assumption.edu 


\section{REFERENCES}

1. Allen, T. (2006). Rewarding good citizens: The relationship between citizenship behavior, gender, and organizational rewards. Journal of Applied Social Psychology, 120-143.

2. $\quad$ Allison, B. J., Voss, R. S., \& Dryer, S. (2001). Student classroom and career success: the role of organizational citizenship behavior. Journal of Education for Business, May/June, 282-288.

3. Astin, A. W. (1977). Four critical years: Effects of college on beliefs, attitudes, and knowledge. San Francisco: Jossey-Bass.

4. Bachrach, D. G., Powell, B. C., Bendoly, E., \& Richey, R. G. (2006). Organizational citizenship behavior and performance evaluations: Exploring the impact of task interdependence. Journal of Applied Psychology, 91(1), 193-201.

5. Bateman, T., \& Organ, D. (1983). Job satisfaction and the good soldier: The relationship between affect and employee "citizenship." Academy of Management Journal, 587-595.

6. Bogler, R., \& Somech, A. (2004). Organizational citizenship behavior in school: How does it relate to participation in decision making? Journal of Educational Administration, 43(5), 420-438.

7. Borman, W. C. (2004). The concept of organizational citizenship. Current Directions in Psychological Science, 13(6), 238-241.

8. Borman, W. C., Penner, L. A., Allen, T. D., \& Motowidlo, S. J. (2001). Personality predictors of citizenship performance. International Journal of Selection and Assessment, 9(1-2), 52-69.

9. Boyle, M. (2004). Walking our talk: Business schools, legitimacy, and citizenship. Business and Society, 43(37), 36-68.

10. Brief, A. P., \& Motowidlo, S. J. (1986). Prosocial Organizational Behaviors. The Academy of Management Review, 11(4), 710-725.

11. Chartrand, J. M. (1990). A causal analysis to predict the personal and academic adjustment of nontraditional students. Journal of Counseling Psychology, 37(1), 65-73.

12. Davis, T. M., \& Murrell, P. H. Turning teaching into learning: The role of student responsibility in the collegiate experience. Retrieved 4/25/11 from http://www.ntlf.com/html/lib/bib/93-8dig.htm

13. Dillman, D. A., Smyth, J. D., \& Christian, L. M. (2009). Internet, mail and mixed-mode surveys: A tailored design method ( $3^{\text {rd }}$ ed.). Hoboken, NJ: John Wiley \& Sons.

14. DiPaola, M. F., \& Tschannen-Moran, M. (2001). Organizational citizenship behavior in schools and its relationship to school climate. Journal of School Leadership, 11, 425-447.

15. Erturk, A. (2007). Increasing organizational citizenship behaviors of Turkish academicians; Mediating role of trust in supervisor on the relationship between organizational justice and citizenship behaviors. Journal of Managerial Psychology, 22(3), 1-11.

16. Farrell, S. K., \& Finkelstein, L. M. (2007). Organizational citizenship behavior and gender: Expectations and attributions for performance. North American Journal of Psychology, 9(1), 81-95.

17. Finkelstein, M. A. (2006). Dispositional predictors of organizational citizenship behavior: Motives, motive fulfillment, and role identity. Social Behavior and Personality, 34(6), 603-616.

18. Hoffman, B .J., Blair, C. A. Meriac, J. P., \& Woehr, D. J. (2007). Expanding the criterion domain? A quantitative review of the OCB literature. Journal of Applied Psychology, 92(2), 555-566.

19. Hui, C., Organ, D. W., \& Crooker, K. (1994). Time pressure, Type A syndrome, and organizational citizenship behavior: A laboratory experiment. Psychological Reports, 75, 199-208.

20. Jimmieson, N. L., Hannam, R. L., \& Yeo, G. B. (2010). Teacher organizational citizenship behaviours and job efficacy: Implications for student quality of school life. British Journal of Psychology, 101, 453-479.

21. Johnson, C. S. (2009). Ties that bind: The interplay between character education, the social studies, and citizenship development. Curriculum and Teaching Dialogue, 11(1-2), 259-274.

22. Kagaari, J. R. K., \& Munene, J. C. (2007). Engineering lecturers' competencies and organizational citizenship behavior (OCB) at Kyambogo University. Journal of European Industrial Training, 31(9), 111 .

23. Kernodle, T. A., \& Noble, D. (2013). Organizational citizenship behavior: It's importance in academics. Journal of Business Education, 6(2), 235-240.

24. Khalid, S. A., Jusoff, H. K., Othman, M., Ismail, M., \& Rahman, N. A. (2010). Organizational citizenship behavior as a predictor of student academic achievement. International Journal of Economics and Finance, 2(1), 65-71. 
25. LePine, J. A. Erez, A., \& Johnson, D. E. (2002). The nature and dimensionality of organizational citizenship behavior: A critical review and meta-analysis. Journal of Applied Psychology, 87(1), 52-65.

26. Moorman, R. H., \& Blakely, G. L. (1995). Individualism-collectivism as an individual difference predictor of organizational citizenship behavior. Journal of Organizational Behavior, 16, 127-142.

27. Motowidlo, S. J., \& Van Scotter, J. R. (1994). Evidence that task performance should be distinguished from contextual performance. Journal of Applied Psychology, 79(4), 475-480.

28. Nguni, S., Sleegers, P., \& Denessen, E. (2006). Transformational and transactional leadership effects on teachers' job satisfaction, organizational commitment, and organizational citizenship behavior in primary schools: The Tanzanian case. School Effectiveness and School Improvement, 17(2), 145-177.

29. Organ, D. W. (1997). Organizational citizenship behavior: It's construct clean-up time. Human Performance, 10(2), 85-97.

30. Organ, D. W. (1988). Organizational citizenship behavior: The good soldier syndrome. Lexington, MA: Lexington Books.

31. Organ, D. W., Podsakoff, P. M., \& MacKenzie, S. B. (2006). Organizational citizenship behavior: Its nature, antecedents and consequences. Thousand Oaks, CA: Sage.

32. Pascarella, E. T., \& Terenzin, P. T. (1991). How college affects students: Findings and insights from twenty years of research. San Francisco: Jossey-Bass.

33. Podsakoff, P. M., \& MacKenzie, S. B. (1997). Impact of organizational citizenship behavior on organizational performance: A review and suggestions for future research. Human Performance, 10(2), 133-151.

34. Podsakoff, P. M., MacKenzie, S. B., Moorman, R. H., \& Fetter, R. (1990). Transformational leader behaviors and their effects on followers' trust in leader and satisfaction, and organizational citizenship behaviors. Leadership Quarterly, 1(2), 107-142.

35. Podsakoff, P. M., MacKenzie, S. B., Paine, J. B., \& Bachrach, D. G. (2000). Organizational citizenship behaviors: A critical review of the theoretical and empirical literature and suggestions for future research. Journal of Management, 26, 513-563.

36. Podsakoff, N., Whiting, S. W., Podsakoff, P. M., \& Blume, B. D. (2009). Individual- and organizationallevel consequences of organizational citizenship behaviors: A meta-analysis. Journal of Applied Psychology, 92(1), 122-141.

37. Pond, III, S. B., Nacoste, R. W., Mohr, M. F., \& Rodriguez, C. M. (1997). The measurement of organizational citizenship behavior: Are we assuming too much? Journal of Applied Social Psychology, 27(17), 1527-1544.

38. Riker, H. C., \& Decoster, D. A. (2008). The educational role in college student housing. The Journal of College and University Housing, 35(2), 80-85.

39. Schmitt, N., Keeney, J., Oswald, F. L., Kim, B. H., Imus, A., Merritt, S., Friede, A., \& Shivpuri, S. (2007). The use of background and ability profiles to predict college student outcomes. Journal of Applied Psychology, 92(1), 165-171.

40. Schmitt, N., Keeney, J., Oswald, F. L., Pleskac, T. J., Billington, A. Q., Sinha, R., \& Zorzie, M (2009). Prediction of 4-year college student performance using cognitive and noncognitive predictors and the impact on demographic status of admitted students. Journal of Applied Psychology, 94(6), 1479-1497.

41. Seachrist, S. R., \& Finnegan, D. E. (2000). Risks and rewards: Good citizenship and technologically proficient faculty. Idea Group Publishing.

42. Skarlicki, D. P., \& Latham, G.P. (1995). Organizational citizenship behavior and performance in a university setting. Revue Canadiennne des Sciences de L'Administration, 12(3), 175-182.

43. Smith, C. A., Organ, D. W., \& Near, J. P. (1983). Organizational citizenship behavior: Its nature and antecedents. Journal of Applied Psychology, 68(4), 653-663.

44. Somech, A., \& Ron, I. (2007) Promoting organizational citizenship behavior in schools: The impact of individual and organizational characteristics. Educational Administration Quarterly, 43(1), 38-66.

45. Vigoda-Gadot, E. (2007). Redrawing the boundaries of OCB? An empirical examination of compulsory extra-role behavior in the workplace. Journal of Business and Psychology, 21(3), 377-405.

46. Wanzian, L., \& Weiwu, W. (2006). A demographic study on citizenship behavior as in-role orientation. Personality and Individual Differences, 42, 225-234. 